\title{
THE IMPORTANCE OF DIGITAL MARKETING FOR WINERIES AND DEVELOPMENT OF WINE TOURISM: CASE STUDY OF SERBIA
}

\author{
Tatjana Pivac ${ }^{1}$ \\ Mirjana Maksimović \\ Ivana Blešić ${ }^{3}$
}

DOI: https://doi.org/10.31410/tmt.2020.241

\begin{abstract}
The wineries recognized the increasingly important role of digital marketing as a valuable and appropriate tool to reach consumers. Wineries owners need to learn to use and apply social media in their marketing activities, as well as which activities are most effective for their needs. This paper intends to provide a brief analysis of digital wine marketing and social media marketing contributions for the wineries to increase brand awareness, sales, and development. The purpose of this research is to investigate social media adoption and engagement amongst wineries and more importantly to understand the activities they use to interact with consumers on social media platforms.

For the purpose of this paper, a structured questionnaire was created. The authors wanted to examine to what extent the wineries are familiar with digital marketing and how much they use it in their own business. The study included 50 wineries across Serbia. Serbian wineries need to be more competitive on the tourist market and understand better the mode of functioning of different systems. The results show that Facebook and Instagram are the main platforms that wineries use to engage with consumers.
\end{abstract}

Keywords: Wineries, Digital marketing, Wine tourism, Serbia.

\section{INTRODUCTION}

$\mathrm{W}$ ine plays an important part in people's lifestyles, and in the last twenty years, an increased interest in visiting the places of production has been witnessed, resulting in rapid growth in the popularity of wine regions around the world and also in Serbia (Molina et al, 2015; Pivac, 2012). As a consequence, numerous wine regions - from Napa Valley in the USA, Barossa Valley in Australia, Tuscany in Italy, Douro Valley in Portugal, Bordeaux, or Provence in France - use their Eno gastronomic riches to promote their territory and develop as a wine tourism destination. Wine is considered the main element in the development and promotion of tourism and is likely to contribute to the creation of wealth at all levels. Wine tourism is a lucrative industry (O'Neill and Charters, 2000), and the success of wine tourism, particularly at the local level, largely depends on how effective marketing and promotion strategies are used and implemented (Galloway et al, 2008; Rasch and Gretzel, 2008). Digital marketing has become an important advertising and information tool, as interactive communication between producer and consumer can be generated. The wineries recognized the increasingly important role of digital marketing as a valuable and appropriate tool to reach consumers, wine lovers, and wine tourists. Since the introduction of Facebook, social media have been put in the spotlight as a new channel for promotion (CBI, 2016).

1 University of Novi Sad, Faculty of Sciences, Department of Geography, Tourism and Hotel Management, Trg Dositeja Obradovića 3, Novi Sad, Serbia

2 Association Women and Wine, Kumodraška 114, Belgrade, Serbia

3 University of Novi Sad, Faculty of Sciences, Department of Geography, Tourism and Hotel Management, Trg Dositeja Obradovića 3, Novi Sad, Serbia; South Ural State University, Institute of Sports, Tourism and Service, 76 Lenin Ave., Chelyabinsk 454080, Russia. 
The phenomenon of social media platforms and increasing customer adoption of these platforms has significantly transformed the way how customers communicate and interact with each other and with businesses (Siamagka et al, 2015; Szolnoki et al, 2018). Social media have transformed consumers from passive observers of content to active participants (Szolnoki et al, 2018). Digital media or social media has become a comprehensive name for all types of communication through various channels such as social networks or mobile applications (Kokić, 2015). Social media usage has been found to contribute positively to brand performance and consumer loyalty (Rapp et al, 2013).

The importance of the internet is high, which is witnessed by the research of Viana (2016) who states that of 7 billion people in the world $42 \%$ of them actively use the Internet and 1,75 billion people use social networks through mobile phones. This shows us the importance of wineries having an online presence and responsive sites which allow proper navigation through access from mobile devices.

There are several studies about the use of social media in the wine industry (Strickland, 2013; Szolnoki et al, 2014; Thach, 2009; Wilson and Quinton, 2012; Dean and Forbes, 2016) but in Serbia, this is the first one. Therefore, the purpose of this research is to investigate social media adoption and engagement amongst wineries, and more importantly to understand the activities they use to interact with consumers on social media platforms.

\section{LITERATURE REVIEW}

Social media are a phenomenon that swiftly positioned itself in the world of marketing. Various profit and non-profit companies, governmental and non-governmental organizations, universities, and individuals were quick to recognize the vast potential of social media (Kokić, 2015). The emergence and spread of the Internet paved the way for the subsequent development of social media.

The rapid rise of social media channels has attracted interest from both academia and industry, keen to understand its nuances and how to strategically adopt, implement and manage for desired results. Social media has grown drastically over the past decade with estimates of more than $32 \%$ of the global population using social media platforms in 2016 (Emarketer, 2016). The highest usage is in China, followed by the USA, Europe, and Asia-Pacific countries (Chaffey, 2016). How Xiang and Gretzel (2010) cite while there is a lack of a formal definition, „social media” can be generally understood as Internet-based applications that carry consumer-generated content which encompasses ,media impressions created by consumers, typically informed by relevant experience, and archived or shared online for easy access by other impressionable consumers" (Blackshaw, 2006). This includes a variety of applications in the technical sense which allow consumers to ,post”, „tag”, „digg”, or „blog”, and so forth, on the Internet. Social media representing various forms of consumer-generated content such as blogs, virtual communities, wikis, social networks, collaborative tagging, and media files shared on sites like YouTube and Flickr, have gained substantial popularity on the Internet (Xiang and Gretzel, 2010; Gretzel, 2006; Pan et al, 2007). Many of these social media Websites help consumers in posting and sharing their travel-related comments, opinions, and personal experiences, which then serve as information for others.

Social media allows for the sharing of different experiences in the form of photos, videos, and stories (Schaffer, 2015; Canovi and Pucciarelli, 2019). Social media thus represents - or at least should represent - an efficient strategic tool to manage, engage and collaborate with travellers, 
providing tourism suppliers with unprecedented opportunities to gain fast, rich, and unmediated consumer insights (Hudson et al, 2015), develop long-term relationships (Ayeh et al, 2012), build brand loyalty (Chan and Guillet, 2011; Laverie et al, 2011) and increase reliability (Dijkmans et al, 2015).

Social media sites are increasingly popular for wine consumers, with the viral and social capabilities of online networks creating a new forum for customer interaction with wine brands (Barber et al, 2008; Bulearca and Bulearca, 2010; Keller, 2009; Leigon, 2011; Aurich, 2019). Also, social media allows consumers to exchange information and encourage others to try different wines (Wilson and Quinton, 2012), so it is a key channel for influencing and affecting wine purchase.

The recent studies show a significant increase in the popularity of social media platforms. Alonso et al. (2013) conducted a study of Italian, Spanish as well as New World wineries that were involved in wine tourism and discovered that $35 \%$ reported using social media. One of the reasons for using it was to communicate with customers about events at the winery. The second main reason was to promote and market wines (Laverie et al, 2011; Aurich, 2019). Wine consumers are frequent users of social media platforms, such as Facebook (Breslin, 2013; Bouquet, 2012). Higgins et al. (2016) showed that $30 \%$ of millennials in the USA use Facebook as a source of information on wine. These millennials were more likely to drink wine on social occasions, buy more wine and spend more on wine each month. Social media plays a crucial role in selling wine since word-of-mouth is more effective than any other manner of selling wine (Leigon, 2011). Small wine producers oftentimes have a limited budget and for them, social media platforms and other free digital marketing tools allow being competitive and building upon the potential digital has to offer (Begalli, 2008).

\section{METHODOLOGY}

For the purpose of this paper, a questionnaire was created based on the methodology used by Szolnoki et al. (2014) was adopted. As basis authors used the questionnaire of the above-mentioned survey. The questionnaire consisted of 7 questions. The second question was open-ended, others were closed. The items, in the fourth question, were measured using a five-point Likert-type scale with the following values: 1 - strongly disagree, 5 - strongly agree.

The survey was conducted in Serbia wineries between 10 of January and 24 of February 2020. The data was collected through an online survey. According to the Wine Register in Serbia exist 355 registered wineries (Jakšić, 2019). About 15\% of wineries participated in the study.

Of the total wineries which are involved in the questionnaire, 3 are large wineries (with more than 20 employees and more than 80 ha of vineyards), 18 are medium-sized wineries (between 10 and 30 employees and from 30 to 80 ha of vineyards), 29 small wineries (have less than 10 employees and less than 30 ha of vineyards).

This survey gives an overview of the social media activities from the winemaker's point of view and shows tendencies in terms of using social media among the winemakers. The data were analyzed with SPSS 25. 


\section{RESULTS}

The analysis shows that a wide variety of communication channels are used in the Serbian wineries. Channels like Facebook, Instagram, website, e-mail are utilized the most (multiple answers were allowed). The following chart represents which channels of communication are most preferably used by wineries in Serbia (Chart 1).

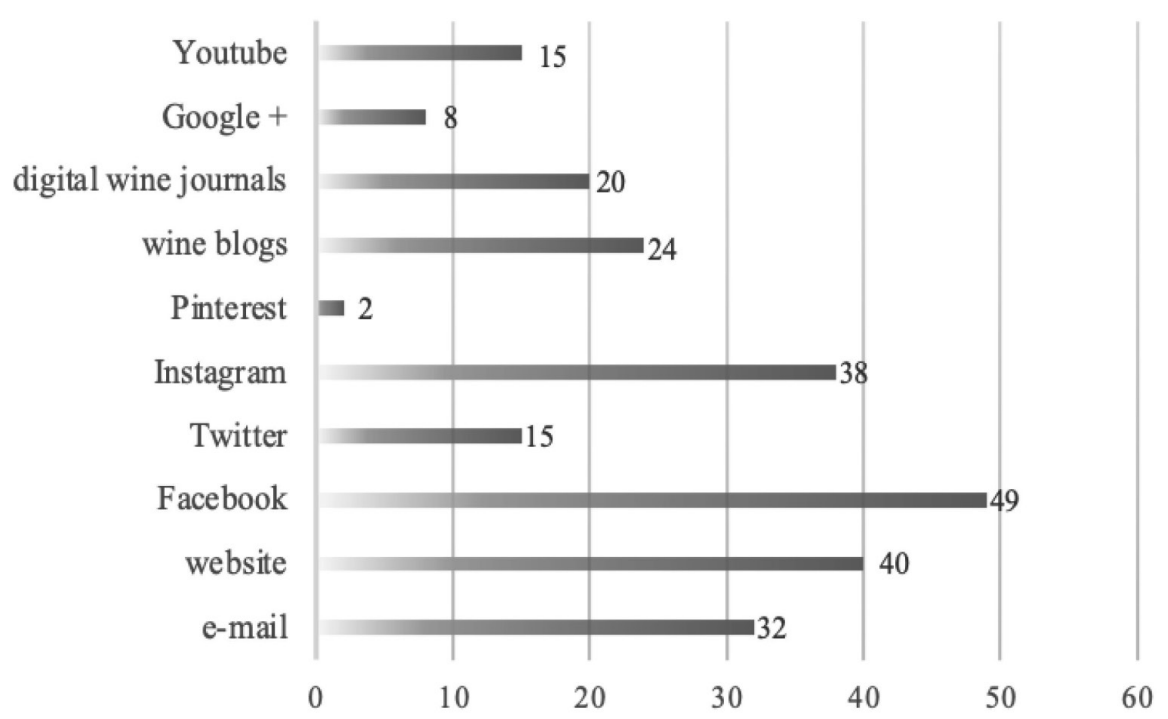

Chart 1. Channels of communication used by wineries

Source: Authors' research

Facebook represents the most important channel for 49 respondents (98\%). 40 respondents $(80 \%)$ have a website. Offering a website can be seen as the basis for online marketing, whereby social media is one way to strengthen look-and-feel goods on top of general marketing techniques. In third place is Instagram, which has registered a growing interest among users and winemakers in recent years.

Table 1. Relevance of digital channels for winemaker's business needs

\begin{tabular}{|c|l|c|c|}
\cline { 3 - 4 } \multicolumn{1}{c|}{} & Frequency & $\%$ \\
\hline \multirow{5}{*}{ Valid } & Facebook & 21 & 42.0 \\
\cline { 2 - 4 } & e-mail & 8 & 16.0 \\
\cline { 2 - 4 } & no one & 1 & 2.0 \\
\cline { 2 - 4 } & Instagram & 5 & 10.0 \\
\cline { 2 - 4 } & Web & 6 & 12.0 \\
\cline { 2 - 4 } & TV & 1 & 2.0 \\
\cline { 2 - 4 } & Digital journal & 1 & 2.0 \\
\cline { 2 - 4 } & fb, Instagram, e-mail & 7 & 14.0 \\
\cline { 2 - 4 } & Total & 50 & 100.0 \\
\hline
\end{tabular}

Source: Authors' research

In terms of Relevance of digital channels for winemaker's business needs (Table 1), it has been determined that most of the wineries (42\%) use Facebook as the main communication channel, followed by e-mail (16\%), a combination of Facebook, Instagram and e-mail (14\%), and the web (12\%). Social networks have different approaches to their respective marketing campaigns. Each enterprise, in this case, a winery, chooses a social network that will bring the most benefit, based on its target consumers and the social network they use. 
Table 2. Hours per day spent working on social networks

\begin{tabular}{|c|c|c|c|}
\cline { 2 - 4 } \multicolumn{1}{c|}{} & Frequency & \% \\
\hline \multirow{4}{*}{} & $\mathbf{1 h}$ & 21 & 42.0 \\
\cline { 2 - 4 } & $\mathbf{2 h}$ & 16 & 32.0 \\
\cline { 2 - 4 } & $\mathbf{3 h}$ & 7 & 14.0 \\
\cline { 2 - 4 } & $\mathbf{4 h}$ & 3 & 6.0 \\
\cline { 2 - 4 } & $\mathbf{5 h}$ & 1 & 2.0 \\
\cline { 2 - 4 } & $\mathbf{5} \mathbf{5 h}$ & 2 & 4.0 \\
\cline { 2 - 4 } & Total & 50 & 100.0 \\
\hline
\end{tabular}

Source: Authors' research

The data in the previous table (Table 2) indicate that the majority of Serbian winemakers (42\%) usually spend 1 hour per day on social networks for business purposes, followed by $32 \%$ who spend 2 hours, and 14\% who spend 3 hours. Only $2 \%$ of the respondents spent 5 hours per day working.

Table 3. The importance of using social networks

\begin{tabular}{|l|c|c|}
\hline Items & Mean & Std. Deviation \\
\hline Sharing information about events at the winery & 4.280 & 0.7010 \\
\hline Public Relations & 4.040 & 1.0683 \\
\hline Consumer Communication & 4.180 & 0.9409 \\
\hline Reaching new consumers & 4.120 & 1.1718 \\
\hline Winery advertising & 4.180 & 1.0437 \\
\hline Notice of winery promo activities & 4.200 & 0.9897 \\
\hline Communication with others (winemakers...) & 3.640 & 1.2415 \\
\hline Product Sales & 3.440 & 1.1808 \\
\hline
\end{tabular}

Source: Authors' research

The results of the descriptive statistics shown in Table 3 indicate that for the surveyed winemakers the most important questions are Sharing information about events at the winery (4.280) and a notice of winery promo activities (4.200). Questions with the lowest values of the arithmetic means of the ratings are Product Sales (3.440) and Communication with others (3.640). The standard deviation is between 0.7010 (Sharing information about events at the winery) and 1.2415 (Communication with others). 92\% of the wineries believe that they can influence the brand image through digital channels, $94 \%$ of them want to build brand strength through these communication channels, but only half of them (52\%) have employed a person in charge of social networking and digital marketing in general. It can be concluded that they know that social media can do the difference, but they still obey to employ one person to do that. The part of the problem could lay in the lack of well-educated persons in a rural environment or in them being lazy to make the effort and find the right person for the job. Empirically speaking, the wineries that have employed the right person has a stronger brand, higher prices, and bigger market share, and a bigger influence on the market.

When asked whether they can influence their brand image using digital channels, as many as 46 $(92 \%)$ of respondents answered positively (Chart 2). Furthermore, 47 (94\%) of respondents stated that they wished to build and influence the strength of the brand through digital communication channels (Chart 3). A brand is not just a name, sign, design, and symbol, but a combination of all of this, which the winery uses to handle its market competition. The concept that the brand represents to consumers decides whether the winery provides everything a consumer wants; from quality and assortment of products to trust, image, and sense of belonging. However, the 
respondents were divided on the question of whether wineries had a person in charge of social networks and digital marketing. Only 26 (52\%) of respondents answered that they have an employee in charge of social media (Chart 4). Today, social media managers are crucial in creating and executing the social media strategies of an enterprise. They focus on increasing brand awareness and attracting and nurturing prospective clients. They are responsible for representing their company brand on social networks. In smaller companies, they can also be in charge of everyday tasks, such as posting on social networks and answering user comments on their social channels.

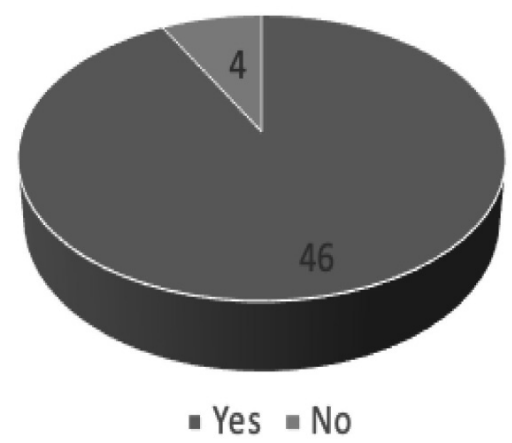

Chart 2. Could you influence your brand image through digital channels?

Source: Authors' research

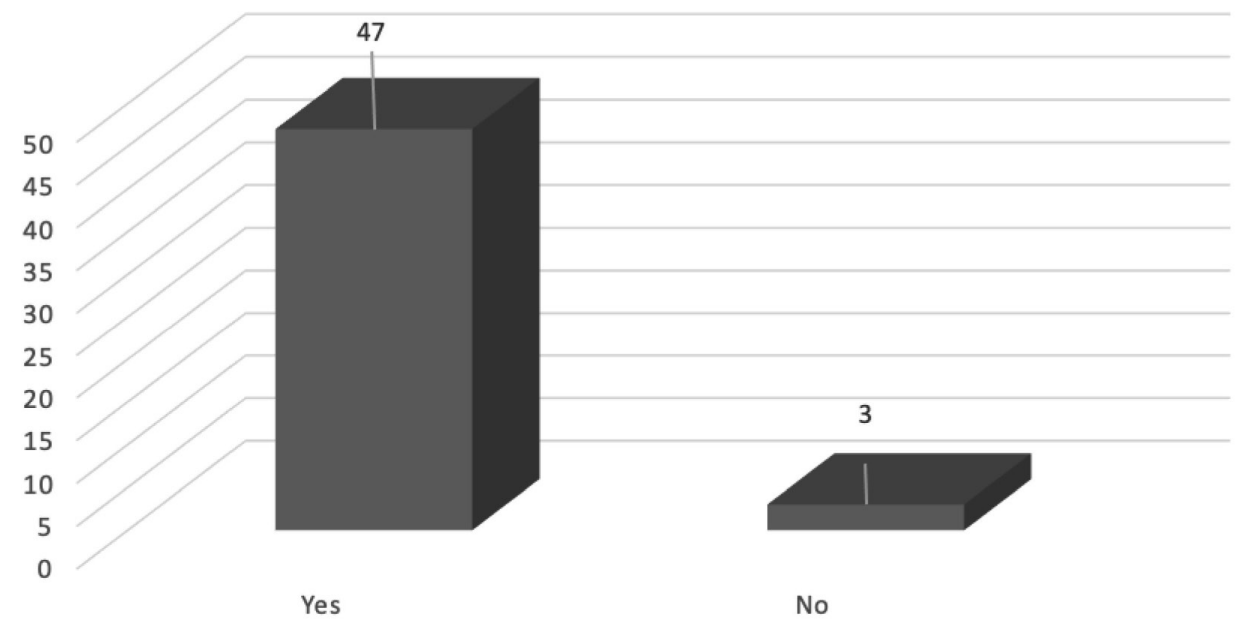

Chart 3. Do you want to build or influence the strength of the brand through digital communication channels?

Source: Authors' research

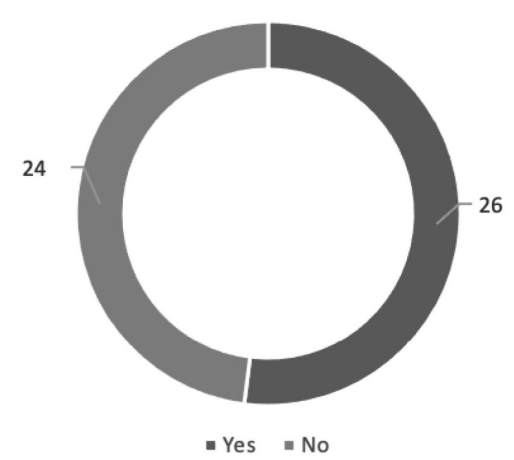

Chart 4. Do you have a person in charge of working on social media and digital marketing in general?

Source: Authors' research 
The results of an independent t-test showed that respondents' attitudes on influencing the brand image through digital channels differed significantly only concerning communication with consumers (Table 4).

Table 4. Results of t-test - Could you influence your brand image through digital channels?

\begin{tabular}{|c|c|c|c|}
\hline Items & Groups & Mean & $\mathbf{t}$ \\
\hline \multirow{2}{*}{ Sharing information about events at the winery: } & Yes (46) & 4.2826 & \multirow{2}{*}{.088} \\
\hline & No (4) & 4.2500 & \\
\hline \multirow{2}{*}{ Public Relations: } & Yes (46) & 4.1087 & \multirow{2}{*}{1.565} \\
\hline & No (4) & 3.2500 & \\
\hline \multirow{2}{*}{ Consumer Communication: } & Yes (46) & 4.2609 & \multirow{2}{*}{$3.546^{*}$} \\
\hline & No (4) & 3.2500 & \\
\hline \multirow{2}{*}{ Reaching new consumers: } & Yes (46) & 4.1957 & \multirow{2}{*}{1.571} \\
\hline & No (4) & 3.2500 & \\
\hline \multirow{2}{*}{ Winery advertising: } & Yes (46) & 4.1957 & \multirow{2}{*}{.356} \\
\hline & No (4) & 4.0000 & \\
\hline \multirow{2}{*}{ Notice of winery promo activities: } & Yes (46) & 4.2391 & \multirow{2}{*}{.947} \\
\hline & No (4) & 3.7500 & \\
\hline \multirow{2}{*}{ Communication with others (winemakers...): } & Yes (46) & 3.7391 & \multirow{2}{*}{$1.970 *$} \\
\hline & No (4) & 2.5000 & \\
\hline \multirow{2}{*}{ Product Sales: } & Yes (46) & 3.5217 & \multirow{2}{*}{1.691} \\
\hline & No (4) & 2.5000 & \\
\hline
\end{tabular}

$* \mathrm{p}<0,05$

Source: Authors' research

Concerning the question of whether they intend to build or influence brand strength through digital communication channels, a significant difference was only found concerning public relations (Table 5). Respondents who nurture public relations were more intent on influencing brand strength through digital channels. However, the results of this and the previous t-test (Table 4) cannot be generalized, since groups are not uniform in size.

Table 5. Results of t-test - Do you want to build or influence brand strength through digital communication channels?

\begin{tabular}{|c|c|c|c|}
\hline Items & Groups & Mean & $\mathbf{t}$ \\
\hline \multirow{2}{*}{ Sharing information about events at the winery: } & Yes (47) & 4.2766 & \multirow{2}{*}{-.135} \\
\hline & No (3) & 4.3333 & \\
\hline \multirow{2}{*}{ Public Relations: } & Yes (47) & 4.1277 & \multirow{2}{*}{$2.406^{*}$} \\
\hline & No (3) & 2.6667 & \\
\hline \multirow{2}{*}{ Consumer Communication: } & Yes (47) & 4.2340 & \multirow{2}{*}{1.635} \\
\hline & No (3) & 3.3333 & \\
\hline \multirow{2}{*}{ Reaching new consumers: } & Yes (47) & 4.1915 & \multirow{2}{*}{1.743} \\
\hline & No (3) & 3.0000 & \\
\hline \multirow{2}{*}{ Winery advertising: } & Yes (47) & 4.1702 & \multirow{2}{*}{-.260} \\
\hline & No (3) & 4.3333 & \\
\hline \multirow{2}{*}{ Notice of winery promo activities: } & Yes (47) & 4.2340 & \multirow{2}{*}{.962} \\
\hline & No (3) & 3.6667 & \\
\hline \multirow{2}{*}{ Communication with others (winemakers...): } & Yes (47) & 3.7234 & \multirow{2}{*}{1.932} \\
\hline & No (3) & 2.3333 & \\
\hline \multirow{2}{*}{ Product Sales: } & Yes (47) & 3.5106 & \multirow{2}{*}{1.707} \\
\hline & No (3) & 2.3333 & \\
\hline
\end{tabular}

$* \mathrm{p}<0,05$

Source: Authors' research 
T-test of independent samples was implemented to determine whether there is a significant difference in respondents' answers on whether they have a person in charge of social media and digital marketing. The results in Table 6. have shown that wineries that do employ people in these positions are much more open towards building public relations and communicating with other wineries. Moreover, wineries that organize human resources in line with digital marketing trends, meaning have employees in charge of social media marketing, give greater importance to their promotional notifications.

Table 6. Do you have a person in charge of working on social networks and digital marketing in general?

\begin{tabular}{|c|c|c|c|}
\hline Items & Groups & Mean & $\mathbf{t}$ \\
\hline \multirow{2}{*}{ Sharing information about events at the winery: } & Yes (26) & 4.4615 & \multirow{2}{*}{1.960} \\
\hline & No (24) & 4.0833 & \\
\hline \multirow{2}{*}{ Public Relations: } & Yes (26) & 4.5769 & \multirow{2}{*}{$4.312^{* *}$} \\
\hline & No (24) & 3.4583 & \\
\hline \multirow{2}{*}{ Consumer Communication: } & Yes (26) & 4.2308 & \multirow{2}{*}{.394} \\
\hline & No (24) & 4.1250 & \\
\hline \multirow{2}{*}{ Reaching new consumers: } & Yes (26) & 4.1538 & \multirow{2}{*}{.211} \\
\hline & No (24) & 4.0833 & \\
\hline \multirow{2}{*}{ Winery advertising: } & Yes (26) & 4.3846 & \multirow{2}{*}{1.459} \\
\hline & No (24) & 3.9583 & \\
\hline \multirow{2}{*}{ Notice of winery promo activities: } & Yes (26) & 4.4615 & \multirow{2}{*}{$2.004 *$} \\
\hline & No (24) & 3.9167 & \\
\hline \multirow{2}{*}{ Communication with others (winemakers...): } & Yes (26) & 4.0000 & \multirow{2}{*}{$2.218^{*}$} \\
\hline & No (24) & 3.2500 & \\
\hline \multirow{2}{*}{ Product Sales: } & Yes (26) & 3.5385 & \multirow{2}{*}{.610} \\
\hline & No (24) & 3.3333 & \\
\hline
\end{tabular}

$* \mathrm{p}<0,01 ; * * \mathrm{p}<0,05$

Source: Authors' research

\section{CONCLUSION}

This study confirms the growing importance of social media in wine tourism. More and more consumers believe information available on the web. Consumers trust recommendations on social channels like Facebook and Instagram. They want to see the real story behind the wine and people having fun while enjoying a glass of it. They want to be addressed through social media channels like Instagram or Pinterest where they can see pictures or comment and tag friends and family to initiate the same experience with their loved ones.

The current study provides a snapshot of wineries. The selection of the wineries was based on an electronic mailing list. Despite these limitations, the results are revealing and provide some key implications for practitioners and new issues for future research.

These results match that Facebook took first place with $98 \%$, website the second (80\%) and Instagram the third (76\%). Social media creates awareness and can influence consumers to visit the vineyard. The use of other social media channels as Pinterest, Google+, and also Yelp (no wineries use it) might be a significant marketing opportunity. Winery owners and managers need to employ digital marketing strategies with experiential posts, appealing images, and stimulating messages. Wine producers need to change their traditional perception of marketing in order to satisfy the needs of their consumers. 
One limitation of this study is the number of wineries involved in the survey, considering that fifty respondents answered the questionnaire. However, this paper is probably the first work that tests the wineries' skills in Serbia of using digital marketing and social media. A suggestion for future research is to compare the use of digital marketing and social networks in countries in the region, for example between Serbia, Croatia, Slovenia, Macedonia, Hungary, and Romania. Further, researchers could investigate the impact of brand loyalty and identification established through digital channels on wine sales, which can strengthen additional interest to adopt an innovative digital marketing approach.

\section{REFERENCES}

Alonso, A., Bressan, A., O'Shea, M., \& Krajsic, V. (2013). Web site and social media usage: implications for the further development of wine tourism, hospitality, and the wine sector. Tourism Planning and Development, Vol. 10, No. 3, 229-248, https://doi.org/10.1080/2156 8316.2012.747989

Aurich, M. (2019). Digital marketing and the construction of brands for small wine producers. NOVA - School of Business and Economics, Portugal

Ayeh, J. K., Leung, D., Au, N., \& Law, R. (2012). Perceptions and strategies of hospitality and tourism practitioners on social media: An exploratory study, in M. Fuchs, F. Ricci, \& L. Cantoni (Eds.). Information and communication technologies in tourism 2012, Springer Verlage, Wienna, Austria, 1-12.

Barber, N., Dodd, T., and Ghiselli, R. (2008). Capturing the younger wine consumer. Journal of Wine Research, Vol. 19, No. 2, 123-141, https://doi.org/10.1080/09571260802622225

Begalli, D., Codurri, S. \& Gaeta, D. (2008). Wine and web marketing strategies: The case study of Italian specialty wineries. British Food Journal, Vol. 111, No. 6, 598-619, https://doi. org/10.1108/00070700910966041

Blackshaw, P. (2006). The consumer-generated surveillance culture, retrieved on 02 February 2020, https://www.clickz.com/the-consumer-controlled-surveillance-culture/69332/.

Bouquet, P. (2012). Social media marketing in the American and French wine industry in 2011. ABLE Social. Media Mark. (Online) https://www.slideshare.net/pierrickbouquet/socialmedia-marketing-in-the-american-and-french-wine-industry-in-2011-13045571/4-SummarySocial_Media_Marketing_has_permeated

Breslin, K. (2013). Presentation on Constellation Digital Marketing in 2012, San Francisco, CA.

Bulearca, M., \& Bulearca, S. (2010). Twitter: a viable marketing tool for SMEs?. Global Business and Management Research: An International Journal, Vol. 2, No. 4, $296-309$.

Canovi, M. \& Pucciarelli, F. (2019). Social media marketing in wine tourism: winery winners' perceptions. Journal of Travel \& Tourism Marketing, Vol. 36, No. 6, 653-664, https://doi. org/10.1080/10548408.2019.1624241

CBI Ministry of Foreign Affairs 2016, CBI Product Factsheet: Online market channels for wine in Europe, retrieved on 02 February 2020, https://www.cbi.eu/sites/default/files/market information/researches/product-factsheet-europe-online-market-channels-wine-2016.pdf

Chaffey, D. (2016). Marketing Trends for 2016 - Will we be in a post-digital era?, retrieved on 02 February 2020, https://www.smartinsights.com/managing-digital-marketing/marketing-innovation/marketing-trends-2016/

Chan, N. L. \& Guillet, B. D. (2011). Investigation of social media marketing: How does the hotel industry in Hong Kong perform in marketing on social media websites? Journal of Travel \& Tourism Marketing, Vol. 28, No. 4, 345-368, https://doi.org/10.1080/10548408.2011.57 1571 
Dean, D.L. \& Forbes, S.L. (2016). Are Customers Having E-Conversations about Your Wine? The Importance of Online Discussion Forums as Electronic Word of Mouth for Wine Marketers. Successful Social Media and Ecommerce Strategies in the Wine Industry, in Szolnoki, G., Thach, L. and Kolb, D. (Eds.), Palgrave Macmillan, New York, NY, 115-132. Dijkmans, C., Kerkhof, P. \& Beukeboom, C. (2015). A stage to engage: Social media use and corporate reputation. Tourism Management, Vol. 47, 58-67, https://doi.org/10.1016/j.tourman.2014.09.005

eMarketer 2016, Nearly One-Third of the World Will Use Social Networks Regularly This Year, retrieved on 03 February 2020, https://www.emarketer.com/Article/Nearly-One-Third-ofWorld-Will-Use-Social-Networks-Regularly-This-Year/1014157

Galloway, G., Mitchell, R., Getz, D., Crouch, G. \& Ong, B. (2008). Sensation seeking and the prediction of attitudes and behaviours of wine tourists. Tourism Management, Vol. 29, No. 5, 950-966, https://doi.org/10.1016/j.tourman.2007.11.006

Gretzel, U. (2006). Consumer generated content - trends and implications for branding. e-Review of Tourism Research, Vol. 4, No. 3, 9-11.

Higgins, L., Wolf, M. \& Wolf, M. (2016). Wine on Facebook: a look at millennials' wine information search, in Szolnoki, G., Thach, L. and Kolb, D. (Eds.), Successful Social Media and Ecommerce Strategies in the Wine Industry, Palgrave Macmillan, New York, NY, 13-29.

Hudson, S., Roth, M. S., Madden, T. J. \& Hudson, R. (2015). The effects of social media on emotions, brand relationship quality, and word of mouth: An empirical study of music festival attendees. Tourism Management, Vol. 47, 68-76, https://doi.org/10.1016/j.tourman.2014.09.001

Jakšić, D. (editor) (2019). Vinogradarstvo i vinarstvo Srbije-studija Analiza sektora proizvodnja i preradi grožđa i proizvodnje, Centar za vinogradarstvo i vinarstvo, Niš

Keller, K.L. (2009). Building strong brands in a modern marketing communications environment. Journal of Marketing Communication, Vol. 15, No. 2-3, 139-155, https://doi. org/10.1080/13527260902757530

Kokić, M. (2015). Brendiranje u digitalnom marketingu na primeru kompanije The new Yourk Times Digital, master rad, Univerzitet Singidunum, Beograd

Laverie, D.A., Humphrey, W., Velikova, N., Dodd, T.H. \& Wilcox, J.B. (2011). Building wine brand communities with the use of social media: a conceptual model, 5th International Conference of the Academy of Wine Business Research, February 08-10, Auckland, New Zealand, 1-7.

Leigon, B. (2011). Grape/Wine Marketing with New Media and Return of the Boomer, Practical Winery \& Vineyard Journal, San Rafael.

Molina, A., Gómez, M., González-Díaz, B. and Esteban, Á. (2015). Market segmentation in wine tourism: Strategies for wineries and destinations in Spain. Journal of Wine Research, Vol. 26, No. 3, 192-224, https://doi.org/10.1080/09571264.2015.1051218

O’Neill, M., \& Charters, S. (2000). Service quality at the cellar door: Implications for Western Australia's developing wine tourism industry. Managing Service Quality: An International Journal, Vol. 10, No. 2, 112-122, https://doi.org/10.1108/09604520010318308

Pan, B., MacLaurin, T. \& Crotts, J. C. (2007). Travel blogs and their implications for destination marketing. Journal of Travel Research, Vol. 46, No. 1, 35-45, doi:10.1177/0047287507302378

Pivac, T. (2012). Vinski turizam Vojvodine monografija, Prirodno-matematički fakultet, Departman za geografiju, turizam i hotelijerstvo, Novi Sad

Rapp, A., Beitelspacher, L. S., Grewal, D. \& Hughes, D. E. (2013). Understanding social media effects across seller, retailer, and consumer interactions. Journal of Academy of Marketing Science, Vol. 41, 547-566 https://doi.org/10.1007/s11747-013-0326-9 
Rasch, L. \& Gretzel, U. (2008). Wineries' involvement in promoting tourism online: The case of Texas. PASOS. Revista De Turismo Y Patrimonio Cultural, Vol. 6, No. 2, 317-326.

Schaffer, V. (2015). Student mentors: Aiding tourism businesses to overcome barriers to social media. Current Issues in Tourism, Vol. 18, No. 11, 1022-1031, https://doi.org/10.1080/136 83500.2014.904847

Siamagka, N.T., Christodoulides, G., Michaelidou, N. \& Valvi, A. (2015). Determinants of social media adoption by B2B organizations. Industrial Marketing Management, Vol. 51, 89-99, https://doi.org/10.1016/j.indmarman.2015.05.005

Strickland, P. (2013). The importance of social media technology of Yarra Valley wineries in Australia, 7th AAWE Conference, June 26-29, Stellenbosch, South Africa, 1-8.

Szolnoki, G. Dolan, R., Forbes, Sh., Thach, L. \& Goodman, S. (2018). Using social media for consumer interaction: An international comparison of winery adoption and activity. Wine Economics and Policy, Vol. 7, No. 2, 109-119, https://doi.org/10.1016/j.wep.2018.07.001

Szolnoki, G., Taits, D., Nagel, M. \& Fortunato, A. (2014). Using social media in the wine business: an exploratory study from Germany. International Journal of Wine Business Research. Vol. 26, No. 2, 80-96, https://doi.org/10.1108/IJWBR-09-2013-0031

Thach, L. (2009). Wine 2.0 - the next phase of wine marketing? Exploring us winery adoption of wine 2.0 components. Journal of Wine Research, Vol. 20, No. 2, 143-157, https://doi. org/10.1080/09571260903169548

Viana, N.A. (2016). Digital wine marketing: Social media marketing for the wine industry, 39th World Congress of Vine and Wine, October 24-28, Bento Gonçalves, Brazil, 1-5, DOI: 10.1051/bioconf/20160703011

Wilson, D. \& Quinton, S. (2012). Let's talk about wine: does Twitter have value? International Journal of Wine Business Research, Vol. 24, No. 4, 271-286, https://doi. org/10.1108/17511061211280329

Xiang, Z. \& Gretzel, U. (2010). Role of social media in online travel information search. Tourism Management, Vol. 31, No. 2, 179-188, doi:10.1016/j.tourman.2009.02.016 
